Gray, E. (1951). J. gen. Microbiol. 5, 840-859.

\title{
The Ecology of the Bacteria of Hobson's Brook, a Cambridgeshire Chalk Stream
}

\author{
BY E. GRAY \\ National Agricultural Advisory Service,* Anstey Hall, Trumpington, \\ Cambridge
}

SUMMARY: The bacteria of the upper reaches of a chalk stream (Hobson's Brook) were studied as part of an inquiry into their association with ciliate protozoa. The bacteria studied were primarily those found in the current core at 2-month intervals as revealed by plating at $22^{\circ}$. The waters of the stream flow from chalk springs through arable land and are swift, cold, alkaline and usually rich in dissolved oxygen. These physical characters generally restricted the microflora to psychrophilic aerobes; but once, when turbulence was lost by damming of the water by a growth of Nasturtium officinale, micro-aerophilic and anaerobic bacteria tended to predominate. Near plants, especially blue-green algae, bacterial numbers were always much higher than in the current core.

The natural indigenous water flora was supplanted, after floods, continued heavy rain, or periods of drought, by a foreign microflora apparently coming from the adjacent soil. The latter flora was apparently modified by agricultural operations on the surrounding arable land and was partly recruited from the rhizospheres of cereal crops thereon.

A tributary stream contaminated by farmyard and domestic waste opens into the Brook but true Escherichia coli were only isolated from its mouth. It is suggested that the topography and turbulence of the Brook combine with protozoan activity to remove polluting bacteria rapidly.

Two strains of Gram-positive micrococci isolated from the Brook induced fission in ciliate protozoa. An unusual type of nitrogen-fixing bacterium was isolated on several occasions.

An investigation was made from October 1946 to January 1949 on the association between the ciliate protozoa and bacteria of Hobson's Brook, a short chalk stream near Cambridge. The inquiry was carried out as a study in microbiological ecology, and was in three parts: a study of the ciliate protozoa, of the bacteria, and of their relationship to the topography, physical factors and biota of the stream. This paper discusses the results obtained from the study of the bacteria. It must be emphasized that the study of the bacteria as such was undertaken only in relation to the whole object of the inquiry.

Topography. The stream flows from chalk springs (Nine Wells springs, Pl. 1, fig. 1) which lie $c .3$ miles south of Cambridge. It is crossed by a main road which divides it into two stretches approximately equal in length: an upper rural reach surrounded by arable land, and a lower urban reach. Only the upper reach received detailed examination, as it is remote from human habitation (Fig. 1). Certain sharp bends made it possible to divide this reach into four arbitrary Zones (Fig. 2):

Zone I was from the springs to a railway culvert 100 yards downstream; a typical spring was chosen to represent this zone.

* This investigation was carried out immediately before joining the Service, at the University School of Botany, Cambridge. 
Zone II extended below the culvert. It had a chalk floor followed by a long stretch of gravel sloping down over the $46 \mathrm{ft}$. contour. The water over the gravel was shallow and swift (Pl. 1, fig. 2).

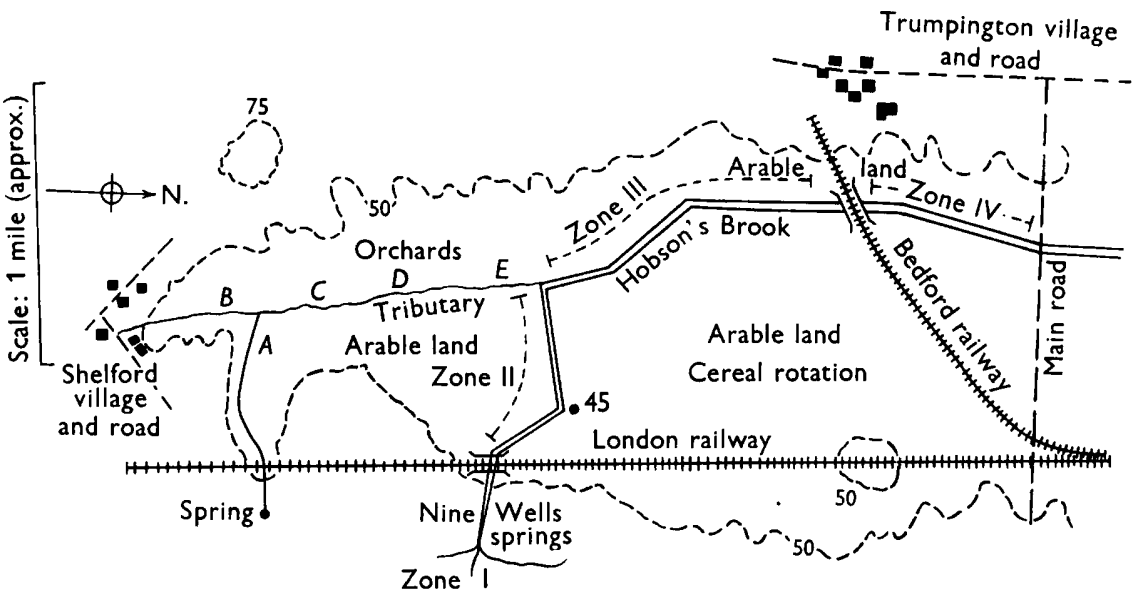

Fig. 1.* The topography of the stream and its tributary, showing the contours (in broken line, - - - ), the main roads (heavy broken line, - - -) and the railways and bridges. The arbitrary zones are marked by Roman capitals and the sampling points in the tributary by the letters $A-E$. The figure 45 in the centre of Zone II is a surveyors' spot level and the water runs swiftly down from this point into Zone III. A second spot level, marked 38 (not shown in the figure), is marked approximately $1200 \mathrm{yd}$. downstream from the main road which terminates Zone IV and some $500 \mathrm{yd}$. from the end of the stream. The fall is therefore only $7 \mathrm{ft}$. from the centre of Zone II to near the point where the stream terminates. Nevertheless, there is always a marked current in the stream, especially in the upper reaches, in contrast to the tributary whose flow is negligible.

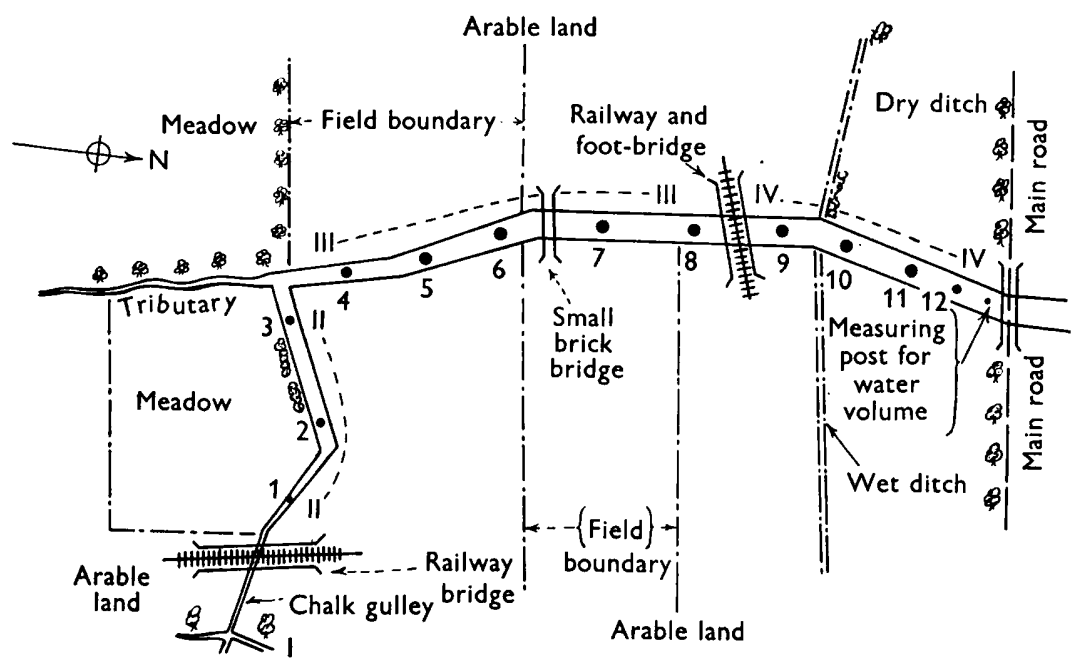

Fig. 2.* The rural reach of the stream showing the Zones (in Roman capitals) and the 12 sampling stations (in Arabic numerals). Trees and hedges exist only where shown; all the bridges pass over the stream allowing a free run of water.

* These maps are based upon the Ordnance Survey Map with the sanction of the Controller of H.M. Stationery Office. 
Zone III ran from the end of Zone II, to a point where the stream is crossed by a second railway line. Its floor was largely composed of earth and chalk, with two patches of gravel (Pl. 1, fig. 3).

$Z$ one $I V$ ran from below the railway bridge to the main road which terminated the reach; it had a floor of deposited silt over chalk and chalk mud (Pl. 1, fig. 4).

Physical characters. The waters of the Brook are cold and alkaline. The upper reaches (Zones I to II and the upper third of Zone III) had a more uniform temperature than the lower reaches (the lower third of Zone III and Zone IV) which were warmer in summer and colder in winter. The typical spring was rheocrene (cf. Carpenter, 1928, p. 225) in character with neutral or slightly acid waters. The reaction in Zone II tended to be almost neutral; through Zones III and IV the water became increasingly alkaline. Some random tests indicated that the winter waters were virtually saturated by oxygen, but as the year progressed the content diminished except in the rapid gravel reach (Zone II), as shown in Fig. 3. The characters of the Zones are summarized in Table 1.

\section{Table 1. The physical features of the Zones of Hobson's Brook}

The Zones are arbitrary but imposed by the topography and rate of flow in each. Fig. 1 shows the surveyors' spot level at the beginning of Zone II and the contours which are responsible for the flow of water in Zone III. The output of the springs was measured at the railway bridge between Zones I and II, immediately below the chalk gulley (Fig. 2). The linear rate of flow was measured in Zone II between sampling points 2 and 3 , and in Zones III and IV opposite the sampling points 5 and 11 (Fig. 2). The floor between sampling points 2 and 3 is gravel, and there are scattered gravel patches between points 6 and 7 , and about point 9 . Elsewhere the floor is chalky, covered by some depth of mud between sampling points 9-12. The bridge between sampling points 8 and 9 (Fig. 2) is double, carrying not only a railway but a footpath. None of the bridges normally causes any obstruction to the rate of flow.

\begin{tabular}{|c|c|c|c|c|}
\hline Zone: & I & II & III & IV \\
\hline Length (yd.): & - & 486 & 868 & 694 \\
\hline $\begin{array}{l}\text { Rate of flow in linear } \\
\mathrm{ft} . / \mathrm{sec} . \text { : }\end{array}$ & $\begin{array}{l}\text { (Output 1.5-2.2 } \\
\text { cu.ft./sec.) }\end{array}$ & 2 & 1 & $0 \cdot 2$ \\
\hline \multicolumn{5}{|l|}{ Temperature $\left({ }^{\circ} \mathrm{C}.\right)$} \\
\hline Maximum: & 10 & 11 & 14 & 15 \\
\hline Minimum: & 8 & 8 & 7 & 5 \\
\hline Average: & 10 & 12 & 12 & 12 \\
\hline pH value: & $6 \cdot 6-7 \cdot 0$ & $7 \cdot 0-7 \cdot 2$ & $7 \cdot 4-7 \cdot 6$ & Up to $7 \cdot 8$ \\
\hline
\end{tabular}

\section{METHODS}

Sampling and counting

The current core only was sampled throughout the investigation. Samples for routine examination were taken from clear water in mid-stream, and at the spring from the jet of water issuing from fissures in the chalk. No samples were taken from the bottom mud, for the stream was so swift that it was considered that at any given time the most representative microflora would be carried along by its current, whereas in the mud the flora would tend to be specialized by sedimentation and anaerobiosis. 
The samples fell into several series:

Series $(i)$. As routine, the current core was sampled every 2 months in each zone. In Zone I, only a single spring was selected for sampling. In Zones II-IV, samples were taken at the points indicated by the Arabic numerals in Fig. 2.

Series (ii). In relation to the numbers and food habits of the associated ciliate protozoa, 100 counts of bacterial numbers at $22^{\circ}$ were made in the early summer of 1947. These samples were taken at the twelve stations (1-12) shown in Fig. 2.

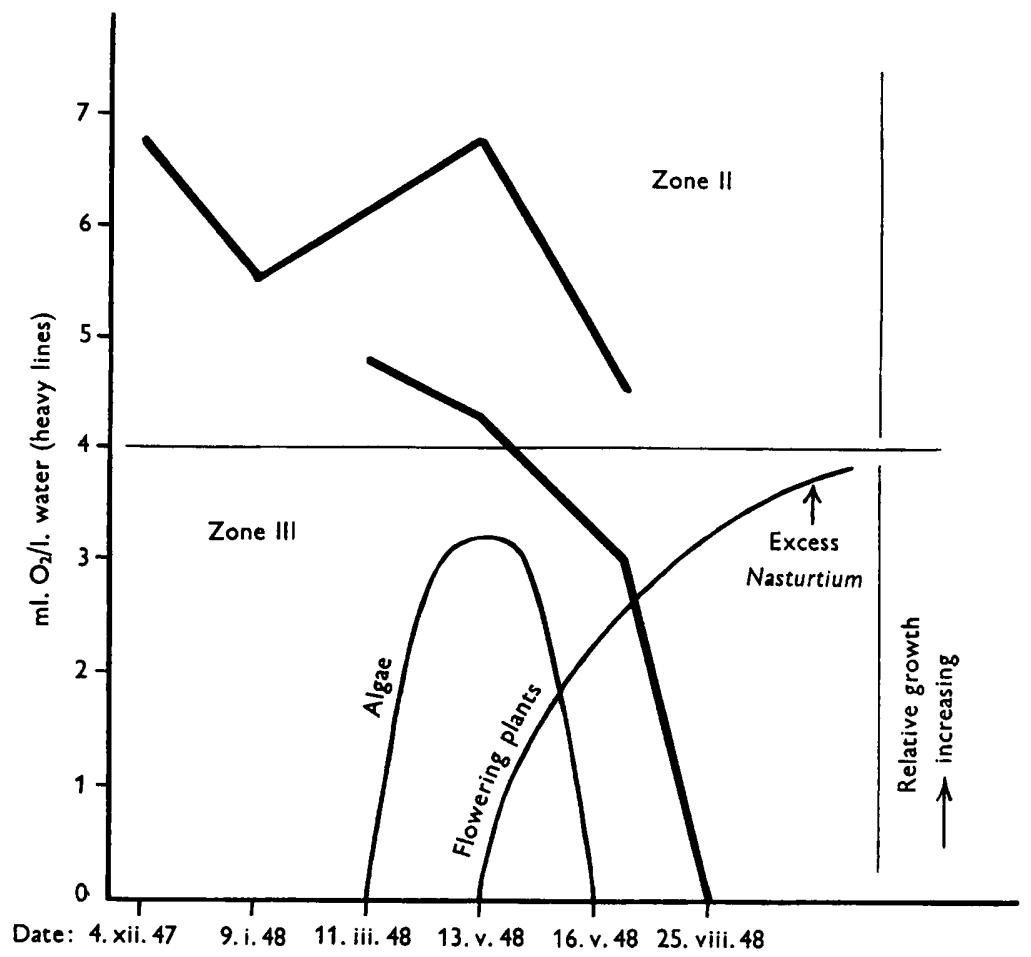

Fig. 3. Dissolved oxygen in the Brook during $1947-8$, estimated by a colorimetric modification of the Winkler technique.

Series (iii). Also in relation to the numbers and food habits of the protozoa, extra samples were taken in the middle third of Zone III in the summer of 1948, twice a week at five fixed points between stations 6 and 8 . In these samples, only the morphology of the bacteria, as shown by Gram-staining, was determined.

Series (iv). In addition, random samples were taken throughout the investigation so far as possible in relation to the twelve fixed points shown in Fig. 2, to examine the microflora associated with eddies or fixed objects such as plants.

Complete bacteriological examination, as described below, was given only to samples from Series $(i)$ and $(i v)$. Samples for bacteriological examination were taken in $8 \mathrm{oz}$. 'medical flat' bottles (capacity approximately $240 \mathrm{ml}$.) which were thoroughly rinsed after use in cold tap water followed by distilled water. 
No detergents were used to clean the bottles, as it was felt important not to introduce any chemicals. The bottles were plugged by cotton-wool covered with Kraft paper and sterilized by dry heat. Before use the cotton-wool was replaced by a sterile rubber stopper, the paper cap being replaced. Samples were taken when working upstream, to avoid contamination by stirred-up mud. The bottles were filled to capacity and after sampling was completed the rubber bung was inserted, recapped with Kraft paper and the temperature of the stream taken. Samples were examined without delay after they were taken, for the bacterial numbers and species quickly changed.

Viable counts were determined as follows. The bottle was well shaken and dilutions made in sterile distilled water. Immediately after the dilution had been made the $\mathrm{pH}$ of the sample was determined colorimetrically. Circumstances limited the writer to one procedure, and the media and times of incubation chosen follow the regulations laid down by the Ministry of Agriculture for the bacteriological examination of farm water supplies. The standard medium used throughout for plating and subculture was a Yeastrelpeptone agar containing $0 \cdot 1 \%(\mathrm{v} / \mathrm{v})$ whole milk, clarified by filtration. At the first few routine tests of the current core, duplicate plates were incubated at $22^{\circ}$ and $37^{\circ}$ respectively, but (except occasionally in Zone IV) a greater number of bacteria developed at $22^{\circ}$ so that incubation at $37^{\circ}$ was not used as a routine procedure (Table 2). Plates were incubated for 4 days at $22^{\circ}$ (or $37^{\circ}$ ) before colonies were counted.

Table 2. Comparative viable counts at $22^{\circ}$ and $37^{\circ}$ in the respective Zones during the first three routine samplings of the current core

$\begin{array}{lcrcc}\text { Zone } & \begin{array}{c}\text { Temp. } \\ \text { of count } \\ \left({ }^{\circ} \text { C. }\right)\end{array} & \overbrace{\text { October }}^{\text {Count (thousands/ml.) }} \\ \text { I } & 37 & 1 & \text { December } & \text { February } \\ \text { II } & 22 & 10 & 1 & 0 \\ & 37 & 2 & 30 & 1 \\ \text { III } & 22 & 22 & 9 & 2 \\ & 37 & 2 & 4 & 19 \\ \text { IV } & 22 & 26 & 10 & 8 \\ & 37 & 216 & 16 & 73 \\ & 22 & 262 & 16 & 14\end{array}$

\section{Isolation and media}

Colonies picked off were purified where necessary after examination of streak cultures in Gram-stained preparations. When pure, they were inoculated into bouillon. Motility was ascertained by examining $12 \mathrm{hr}$. cultures in peptone water; alternatively a drop of the peptone water culture was allowed to diffuse over the surface of nutrient agar for $12 \mathrm{hr}$. when the edge of the drop was cut out and the organisms allowed to diffuse in watch-glasses containing peptone water or sterile saline.

After the morphology of an organism had been ascertained it was tested as a routine in nine media: glucose broth (for the Voges-Proskauer and Methyl 
Red reactions); nitrate broth ( $0.1 \%$ potassium nitrate in peptone water); bouillon or nutrient (Lab-Lemco) broth; nutrient gelatin (made with LabLemco broth); litmus milk (skimmed-milk powder); glucose broth ( $1 \%$ glucose in peptone water with $\mathbf{0 . 2 5} \%(\mathrm{v} / \mathrm{v})$ of $1 \%$ aqueous solution of neutral red as indicator); inorganic (peptone free) sugar media containing $1 \%$ salicin, lactose or maltose with bromcresol purple as indicator.

Gram-negative rods which gave a positive v.P. or M.R. reaction were further tested in a citrate medium (virtually Koser's, except that citric acid was used instead of sodium citrate following the formula of the Ministry of Health Report no. 71, 1939). All media were adjusted to $\mathrm{pH} \mathbf{7 \cdot 2 - 7 \cdot 4}$ and tested for sterility by incubation at $22^{\circ}$ and $37^{\circ}$.

When spore-formers dominated the microflora, a test was made to detect anaerobic strains. A few drops of a 24-48 hr. bouillon culture were added to a sterile tube of whole milk sealed with sterile liquid paraffin. The whole was then pasteurized at $80^{\circ}$ for $30 \mathrm{~min}$., allowed to cool and incubated at $37^{\circ}$ for 2 days. Stormy fermentation in the curd and the production of a clear whey indicated the presence of Clostridium welchii which, as a typical form, was regarded as an indicator.

\section{RESULTS}

The quantitative aspect

Table 3 gives the total bacterial numbers obtained in the current core of each Zone from the samples of Series $(i)$. Three things appear from this table: (a) The general level of the counts, even in Zone I, was rather higher than that usual in the waters of springs. (b) There was a general increase in bacterial numbers downstream to Zones III and IV, especially in the latter. This was associated with increase in alkalinity, increase of organic content in the water, and increased opportunity for contamination. (c) There was a strong suggestion that the bacteria were more numerous in 1948 than in 1947. This may have been related to the high rainfall in 1948 (as will shortly be seen) which is likely

Table 3. Number of viable bacteria at $\mathbf{2 2}^{\circ}$ obtained from the samples of Series (i), from October 1946 to December 1948

\begin{tabular}{|c|c|c|c|c|c|c|c|}
\hline \multirow[b]{2}{*}{ Zone } & \multirow[b]{2}{*}{ Year } & \multicolumn{6}{|c|}{ Number of viable bacteria $\left(10^{3} / \mathrm{ml}\right.$.) } \\
\hline & & February & April & June & August & October & December \\
\hline I & $\begin{array}{l}1946 \\
1947 \\
1948\end{array}$ & $\begin{array}{l}0.5 \\
0.5 \\
0.5\end{array}$ & $\begin{array}{l}\dot{1} \\
8 \cdot 5\end{array}$ & $\begin{array}{r}\dot{2} \\
60\end{array}$ & $\begin{array}{l}\dot{2} \\
\mathbf{2}\end{array}$ & $\begin{array}{c}5 \\
14 \\
0.5\end{array}$ & $\begin{array}{r}15 \\
40 \\
228\end{array}$ \\
\hline II & $\begin{array}{l}1946 \\
1947 \\
1948\end{array}$ & $\begin{array}{l}\dot{9} \cdot 5 \\
2\end{array}$ & $\begin{array}{l}\mathbf{3} \\
\mathbf{1}\end{array}$ & $\begin{array}{l}\dot{3} \\
8 \cdot 5\end{array}$ & $\begin{array}{c}\dot{14.5} \\
8\end{array}$ & $\begin{array}{l}11 \\
22 \\
14.5\end{array}$ & $\begin{array}{c}4 \\
200 \\
4 \cdot 5\end{array}$ \\
\hline III & $\begin{array}{l}1946 \\
1947 \\
1948\end{array}$ & $\underset{3}{12 \cdot 5}$ & $\begin{array}{c}\dot{3} \\
12 \cdot 5\end{array}$ & $\begin{array}{r}. \dot{16} \\
24\end{array}$ & $\begin{array}{c}4 \cdot 5 \\
363\end{array}$ & $\begin{array}{l}13 \\
20 \\
12 \cdot 5\end{array}$ & $\begin{array}{r}5 \\
215 \\
6 \cdot 5\end{array}$ \\
\hline IV & $\begin{array}{l}1946 \\
1947 \\
1948\end{array}$ & $\begin{array}{r}7 \\
11\end{array}$ & $\begin{array}{r}193 \\
9\end{array}$ & $\begin{array}{l}\dot{18} \\
16 \cdot 5\end{array}$ & $\begin{array}{r}50 \\
\mathbf{3 4 1}\end{array}$ & $\begin{array}{c}131 \\
60 \\
4.5\end{array}$ & $\begin{array}{r}5 \\
49\end{array}$ \\
\hline
\end{tabular}


to have resulted in increased numbers of soil organisms being washed into the stream. Topley \& Wilson's Principles (1946, p. 2018) quotes similar observations.

The effect of excessive rainfall is illustrated by Fig. 4, which shows the relation between the bacterial numbers in Zone IV and the water volume during the thaw that followed the severe winter of 1947. It is plain from Fig. 4 that as the water-level increased so did the numbers of bacteria in the water. It is presumed that this was due to soil washed into the stream, for the water was very turbid and contained organisms of soil type, e.g. Pseudomonas fluorescens and Escherichia coli irregulars (compare Table 4 below). Such effects would be more noticeable in the lower Zones. No attempt was made to relate the bacteria of the water at the springs to rainfall, as this water was filtered through the chalk.

Table 4. Bacteria isolated from the current core. (The numbers in brackets indicate the Zones where the bacteria were generally. found)

Members of all these species occurred irregularly in all Zones at all seasons of the year (except for Chromobacterium violaceum var., and Flavobacterium spp.-see p. 847). Although in general distribution was irregular, certain species were more common in certain months than at other times, as indicated.

\section{Identified}

Aerobacter aerogenes var. (II.) Isolated once, in December 1946.

Escherichia coli Intermediate Type 2. (II.) Isolated in April and August 1948.

Esch. cloacae var. ceratophyllum. (III.) Isolated once, in October 1946.

Bacillus mycoides. (I, IV.) Isolated sporadically: v. common. October 1946, April 1949.

Chromobacterium prodigiosum. (IV.) Isolated in October 1946 only.

C. violaceum var. (III, IV.) Isolated in February and April 1947 only.

Pseudomonas fluorescens non-liquefaciens. (III). October 1947 and February 1948 only. $P$. fluorescens-liquefaciens. (III.) In June 1948 only.

\section{Unidentified}

Achromobacterium spp.? (I II, III, IV.) Isolated in October, December 1948.

Actinomyces spp. (I, II, III, IV.) Most common in the spring of 1948 .

Bacillus spp. (I, II, III, IV.) Most common in the late summer of 1947, and the spring of 1949.

Bacterium spp. (I, II, III, IV.) Most common in June 1947 and April 1948.

Bacterium (chromogenic) spp. (III, IV.) Isolated in February and June 1947.

Esch. coli var. (I, II, III, IV.) Most common in April, August 1947, June 1948.

Corynebacterium spp. (I, II, III, IV.) Most common in December 1946, and August and October 1948.

Chromobacterium (Flavobacterium) spp. (I, II, III, IV). Dominated the bacterial flora from December 1946 to February 1947; not subsequently isolated.

Lactobacillus spp. (III.) Common in December 1948.

Micrococcus spp. (I, II, III, IV.) Generally speaking commonest in the springs in winter, in spring and summer elsewhere.

Micrococcus (chromogenic) spp. (I, II, III, IV.) Irregular in occurrence.

Pseudomonas spp. (I, II, III, IV.) Commonest in June 1947, February 1948, April 1949.

Variation of temperature usually causes an inverse variation of bacterial numbers in water of low organic content, and a direct yariation in waters of high organic content (e.g. Topley \& Wilson's Principles, 1946, p. 2018). On this basis it might have been expected that counts in Zone II would be lower in summer than winter, and in Zone IV higher in summer than in winter for, as 
compared with other zones, Zone IV had a high silt content. The data of Fig. 5, however, show no such relations. There is some suggestion of an increase of bacterial numbers in winter but it is not clearly related to the low temperatures. One would conclude that in this stream the influence of temperature is insignificant compared with that of rainfall.

\section{The qualitative aspect}

Early in the investigation it was found that a division could be made into an indigenous flora of water bacteria and a foreign flora apparently derived from soil. The natural water flora comprised species of Bacterium, Pseudomonas, Flavobacterium, Chromobacterium and perhaps Micrococcus. The foreign flora consisted of Gram-positive spore-forming rods such as Bacillus mycoides, B. subtilis; Gram-positive non-sporing rods, such as Corynebacterium and Lactobacillus spp., together with species of Actinomyces; and Gram-negative rods such as Aerobacter aerogenes and atypical Esch. coli.

The distinction between the natural water microflora and that from external sources is somewhat arbitrary, but it is drawn partly from Taylor (1942), who stated that as compared with soil the chief difference is the absence from water of the genera Mycobacterium and Corynebacterium and of Bact. globiforme Conn, and is also based upon the typical members of the soil microflora as given by Waksman (1928). It was found, too, that in general the members of the natural water flora had little biochemical activity (cf. Taylor, 1942), whereas the activities of the foreign flora were more pronounced.

In addition, there was a large group of obscure Gram-negative rods with feeble biochemical activities whose exact nature was not determined and which were much in evidence in 1948. The only organism found to fix atmospheric nitrogen was a new form, isolated from the Brook and also from the Cam and a neighbouring stream the Bourn Brook (Gray \& Smith, 1950).

A list of the types isolated is given in Table 4. Only in relatively few instances did the organism appear to have been previously described. On the basis of morphology, cultural and physiological characteristics it was possible to get close to naming species of Flavobacterium and Pseudomonas. Some of the obscure Gram-negative rods (non-motile or motile with peritrichous flagella) appeared to be achromobacteria, whilst others produced pigment (red, orange or dirty white to yellow); Gram-negative rods producing pigment are stated by Taylor (1942) to be characteristic water bacteria. Cultural characters of some of these Gram-negative rods are given in Table 5.

\section{The natural bacterial flora}

Although temperature had no obvious effect upon the number of bacteria, it had an effect on the nature of the bacterial flora, and so indirectly upon bacterial numbers. The water of the Brook is cold and its bacterial flora is largely composed of psychrophilic bacteria (optimum temperatures below $20^{\circ}$; Thomas \& Sekhar, 1946). When during the severe winter of 1946-7 the Brook temperatures fell to an average of $6^{\circ}$, there appeared strains of Chromobacterium 
violaceum (isolated by Schmelch (1888) from melting glacial snow and from the Thames in winter by Ward (1898)), followed almost at once by a great efflorescence of flavobacteria which dominated the flora everywhere in the stream. Chr. violaceum did not appear in February 1948 when the Brook

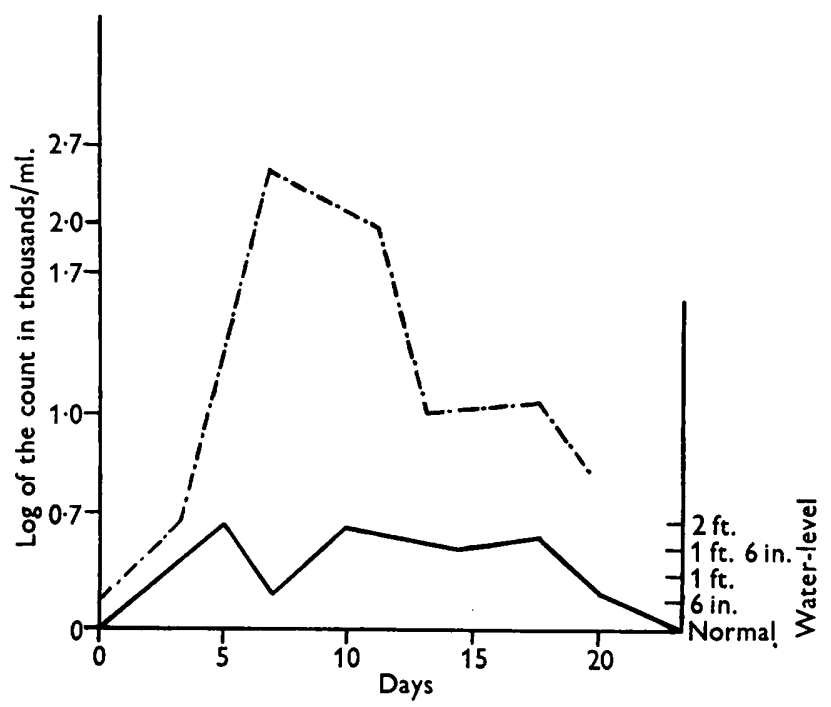

Fig. 4. Viable counts at $22^{\circ}$ and water volume in Zone IV during the great thaw of March 1947.

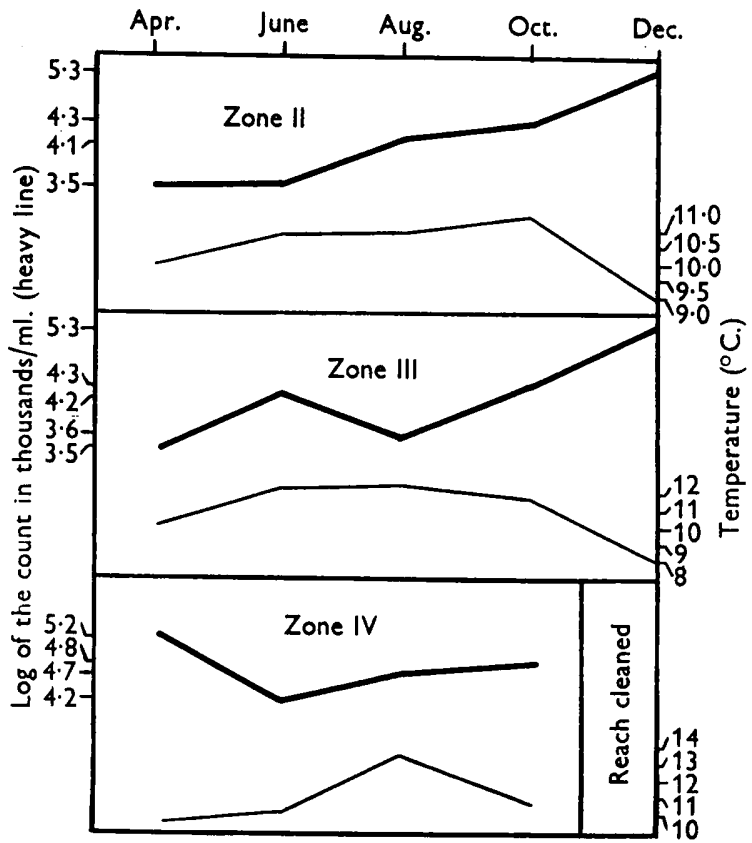

Fig. 5. Temperature and viable counts (bimonthly sampling) in the various Zones during the summer and winter of 1947 . 


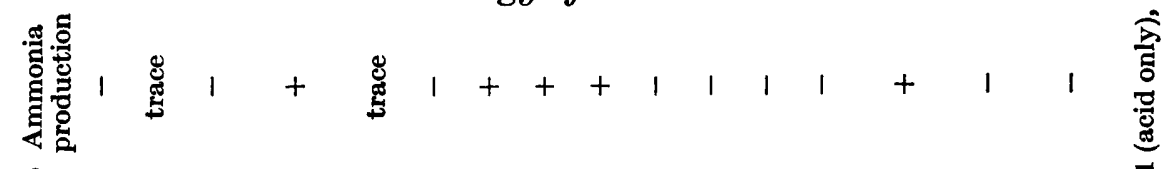

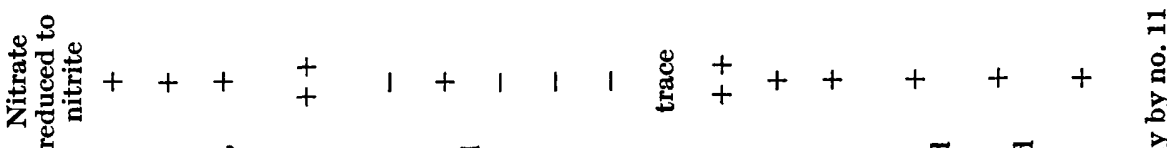

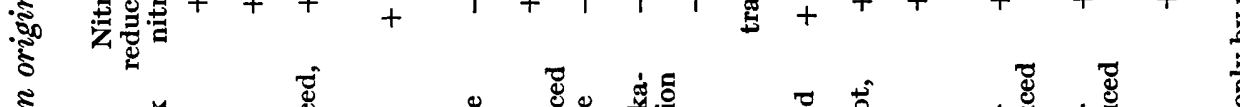

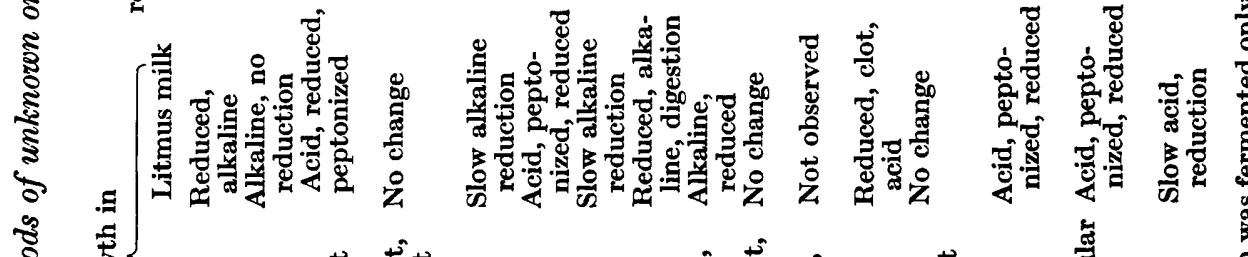
胥 हैं

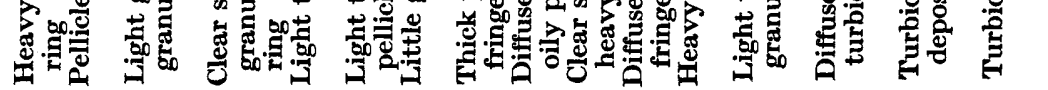

$\stackrel{5}{5}$

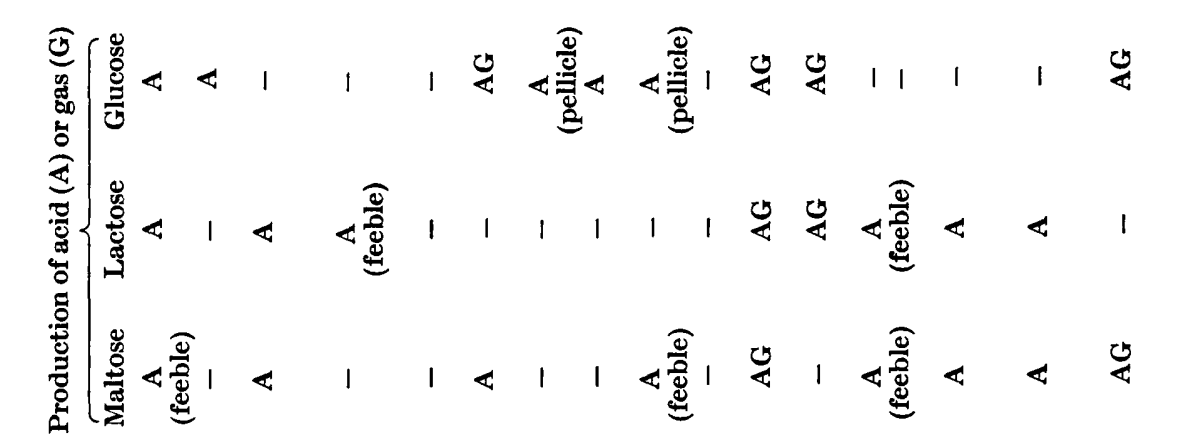

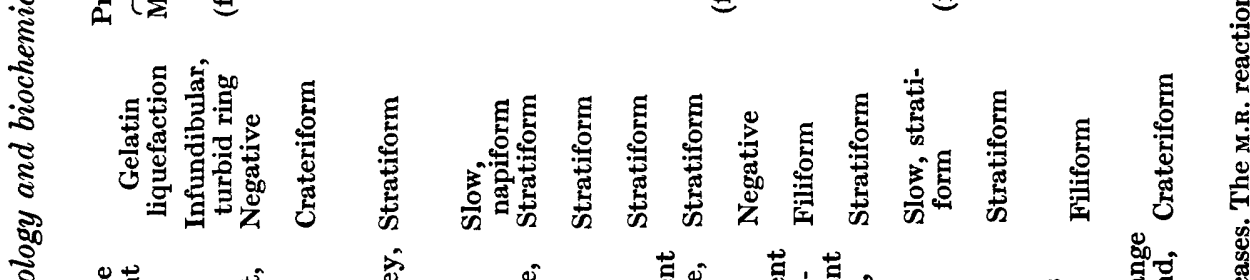

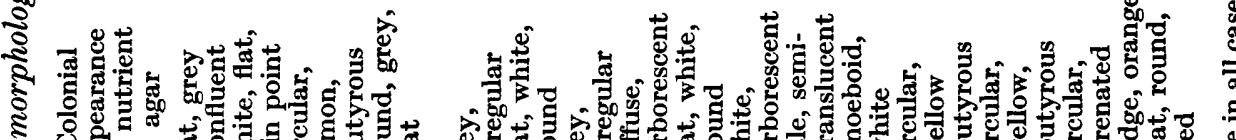
ั

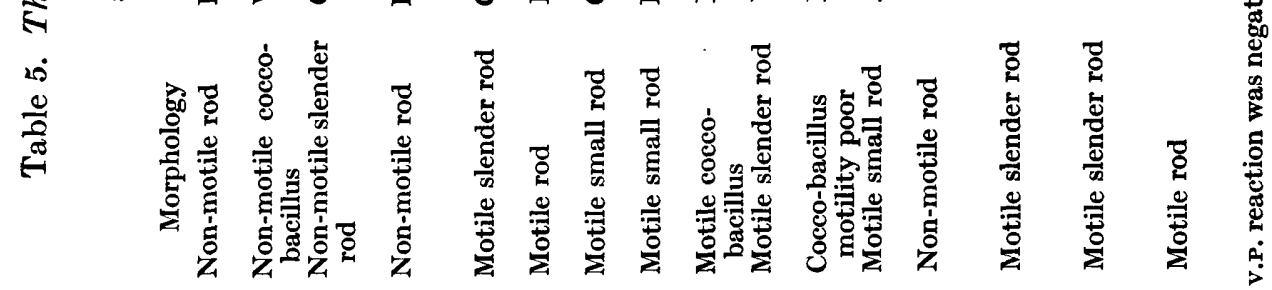
芸 GMV5 
temperature was $8-9^{\circ}$ nor did flavobacteria except in isolated instances. During the bimonthly examinations carried out from 1 October 1946 to 1 October 1948, 48 strains of bacteria from the springs of Zone I, 47 strains from Zone II, 47 strains from Zone III, and 50 strains from Zone IV received detailed examinations, and it was generally found that those organisms regarded as true water forms (e.g. achromobacteria, micrococci? and chromogenic bacteria) tended to occur late in the year or in January and February, when the temperatures were lower.

As regards the Micrococcus spp. it was doubtful whether or not they were true water forms. All were Gram-positive but none was exactly identified. Though they were common in the Brook, they were not rare in the soil of the banks. When the cultural characteristics of four strains isolated from Zone III were compared with four strains isolated from the soil of the banks of Zone III, the first four strains of soil micrococci all liquefied gelatin rapidly, whereas those from the brook did not (Table 6). Subsequently, however, soil strains were isolated from the banks which did not liquefy gelatin, and water strains which did liquefy it within a few days. Certain of these strains were subcultured during nearly 2 years and did not change their morphology, showing that they were true micrococci and not pleomorphic strains of $\dot{B a c t}$. globiforme Conn. Further, filtrates of two of these strains induced binary fission in ciliate protozoa; Sonneborn (1932) found that chain formation in Colpidium colpoda was induced by a strain of Micrococcus sensibilis.

Table 6. Cultural reactions of micrococci isolated in December 1947 from the current core of Hobson's Brook, and from soil within 10 yards of the banks

\begin{tabular}{|c|c|c|c|c|c|c|}
\hline \multirow[b]{2}{*}{ Strain } & \multirow{2}{*}{$\begin{array}{l}\text { Gelatin } \\
\text { stab }\end{array}$} & \multicolumn{3}{|c|}{ Formation of acid (A) or gas (G) } & \multirow{2}{*}{$\begin{array}{c}\text { Litmus } \\
\text { milk }\end{array}$} & \multirow{2}{*}{$\begin{array}{l}\text { Nitrate } \\
\text { reduced } \\
\text { to nitrite }\end{array}$} \\
\hline & & $\overparen{\text { Salicin }}$ & Lactose & Maltose & & \\
\hline 1 & Infund. & $\mathbf{A}$ & - & - & $\begin{array}{l}\text { Peptonized } \\
\text { reduced }\end{array}$ & ++ \\
\hline 2 & Infund. & $\mathbf{A}$ & A & A & $\begin{array}{l}\text { Peptonized } \\
\text { reduced }\end{array}$ & - \\
\hline 3 & Stratif. & - & 一 & $\mathbf{A}$ & $\begin{array}{l}\text { Peptonized } \\
\text { reduced }\end{array}$ & ++ \\
\hline 4 & Stratif. & - & 一 & - & $\begin{array}{l}\text { Peptonized } \\
\text { reduced }\end{array}$ & ++ \\
\hline 5 & $\begin{array}{l}\text { Not } \\
\text { liquef. }\end{array}$ & - & - & - & $\begin{array}{l}\text { Slightly } \\
\text { alkaline }\end{array}$ & + \\
\hline 6 & $\begin{array}{l}\text { Filiform } \\
\text { growth, no } \\
\text { liquef. }\end{array}$ & - & - & - & No change & 一 \\
\hline 7 & Not liquef. & - & - & $\begin{array}{c}\text { Feeble A } \\
\text { (glucose) }\end{array}$ & No change & - \\
\hline 8 & $\begin{array}{l}\text { Filiform, no } \\
\text { liquef. }\end{array}$ & - & - & - & $\begin{array}{l}\text { Slightly } \\
\text { alkaline }\end{array}$ & - \\
\hline
\end{tabular}

\section{The foreign bacterial flora}

The foreign bacterial flora, presumed to come from the soil, appeared after rain and also after prolonged periods of hot dry weather when soil continually crumbled into the water. But for this foreign flora to dominate the microflora 
of the Brook, it was necessary for such climatic conditions to act over a considerable period of time. When earth was constantly washed in during prolonged showery weather, or continually crumbled into the stream during droughts, the effect was more lasting than that of a sudden flood which dispersed as quickly. Considerable floods appeared, for example, in March 1947 and filled the stream with soil, but by April of that year when the water subsided only a few soil bacteria were present (e.g. Actinomyces sp. in Zone III, unidentified spore-formers in Zone IV). By contrast, in August 1947 after a hot dry summer, when soil had been constantly observed to fall into the stream, especially under the concussion of agricultural machinery during harvesting, soil bacteria dominated the flora, Esch. coli irregulars and B. subtilis being isolated from all Zones.

The character of the foreign flora entering the Brook was considered to be largely determined by the agricultural operations on the surrounding land. Severin (1895; quoted by Waksman, 1927) found rods to predominate in freshly-ploughed soil but within 2 weeks micrococci predominated. Table 7 shows that when the arable land surrounding the Brook was ploughed in the late summer and early autumn of 1946, 1947 and 1948, micrococci were very numerous in all Zones (including the springs) in the autumn of 1946 and 1947 and dominated the flora in Zones I-III in the winter of 1947 (Zone IV was not sampled as workmen were clearing it out). Again, aerobic micrococei were present in all Zones (see Table 7) in the late summer of 1948, while microaerophilic cocci dominated the micro-flora in Zones II-IV in October 1948, the dominance persisting into December except in Zone IV.

Sheep were folded beside Zone III before ploughing there in the autumn of 1947 and 1948, and at the end of July and the beginning of August 1948 the land bordering the opposite bank to that on which sheep were folded was very heavily dressed with farmyard manure, far more heavily than at any other time during the investigation. In the middle of August 1948 there was a sudden and excessive growth of Nasturtium officinale (watercress) in Zone III which rapidly filled the reach (Pl. 1, fig. 5), spread far down into the upper third of Zone IV and by damming the water converted Zone II into a stagnant pool and drowned the springs. This excessive growth was attributed, in the absence of other evidence, to a conjunction of very heavy dressing of the land with manure with a fortnight of hot bright weather. The land was ploughed about the time the manure was applied, and as mentioned micrococci dominated the microflora in Zones II-IV in October 1948. The stagnation of the water caused by the damming of the current by watercress was possibly responsible however for the fact that the micrococci were universally microaerophilic, whereas at all other times they were aerobic. Although the watercress died back during the winter except for sporadic patches, aerobic sporeformers with some clostridia (i.e. $\mathrm{Cl}$. welchii) were prominent in the microflora of Zones III and IV in the early spring of 1949 and may have been derived from the heavy dressing of manure.

It was previously mentioned that a large group of Gram-negative rods was isolated whose exact position was not determined. Lochhead, Timonin \& 


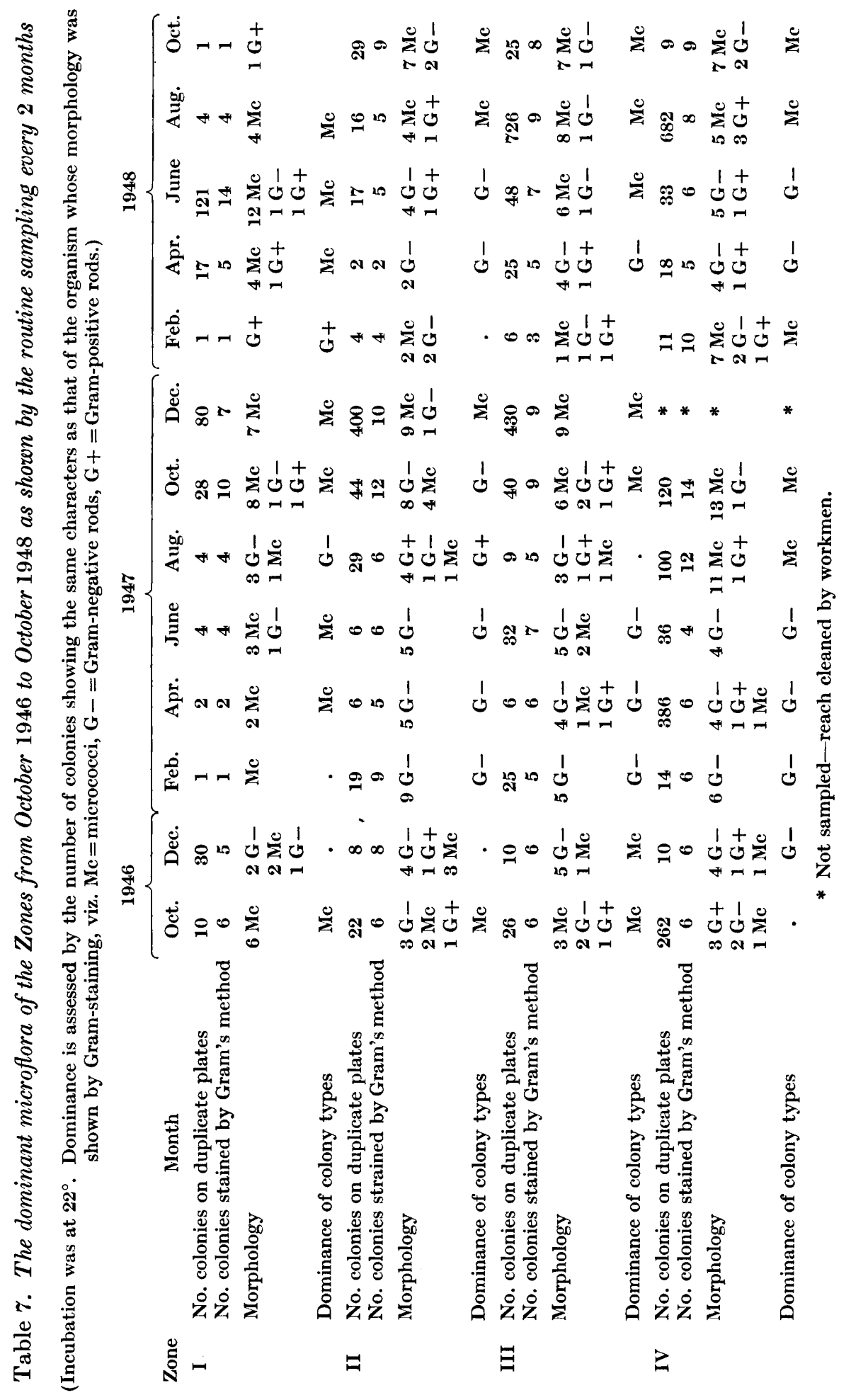


West (1940) showed that the rhizospheres of plants (notably cereal crops) are associated with a particular microflora; Gram-negative rods, for example, were found to predominate in the rhizospheres of oats, wheat and barley, and also in those of grass, e.g. clover. Gram-negative rods dominated the bacterial flora of Zone III when cereal crops were growing on its banks, and the same phenomenon was noted in Zones II and III in the spring and early summer of 1947 and 1948, and in Zone IV in the spring of 1948.

It is suggested that since soil constantly entered the Brook from climatic and other causes, the obscure group of Gram-negative rods isolated from the water possibly came from the rhizospheres of crop plants, which grew right up to the edge of the banks; moreover, the drainage of the subsoil was towards the stream. The dominance of Gram-negative rods in the bacterial flora as found in the routine sampling is shown in Table 7. The association between the bacterial flora of crop rhizospheres as given by Lochhead et al. (1940) and that found in the Brook from all examinations is given in Table 8.

Table 8. Comparison of the dominant bacterial flora (as shown by all examinations of the current core), in the several Zones, with the supposed $\left(^{*}\right)$ microflora of the rhizospheres of the crops growing on either bank of the Brook

\begin{tabular}{|c|c|c|c|c|c|c|c|c|c|}
\hline \multirow[b]{2}{*}{ Zone } & \multirow[b]{2}{*}{ Year } & \multirow[b]{2}{*}{ Crop } & \multicolumn{3}{|c|}{$\begin{array}{l}\text { Crop rhizospheres } \\
\text { microflora }\end{array}$} & & \multicolumn{3}{|c|}{ Brook } \\
\hline & & & $\begin{array}{l}\text { G+ } \\
\text { rods }\end{array}$ & $\begin{array}{l}\text { G- } \\
\text { rods }\end{array}$ & $\begin{array}{l}\text { Micro- } \\
\text { cocei }\end{array}$ & Season & $\begin{array}{l}\text { G+ } \\
\text { rods }\end{array}$ & $\begin{array}{l}\text { G- } \\
\text { rods }\end{array}$ & $\begin{array}{l}\text { Micro- } \\
\text { cocci }\end{array}$ \\
\hline \multirow[t]{2}{*}{ II† } & 1947 & Barley & $\mathbf{0}$ & 4 & $\mathbf{0}$ & $\begin{array}{l}\text { Spring } \\
\text { Summer }\end{array}$ & $\begin{array}{l}\mathbf{0} \\
\mathbf{0}\end{array}$ & $\begin{array}{l}4 \\
4\end{array}$ & $\begin{array}{l}\mathbf{0} \\
\mathbf{0}\end{array}$ \\
\hline & 1948 & Meadow grass & $\mathbf{0}$ & 4 & $\mathbf{0}$ & $\begin{array}{l}\text { Spring } \\
\text { Summer }\end{array}$ & $\begin{array}{l}\mathbf{0} \\
\mathbf{0}\end{array}$ & $\begin{array}{l}1 \\
4\end{array}$ & $\begin{array}{l}\mathbf{1} \\
\mathbf{0}\end{array}$ \\
\hline \multirow[t]{2}{*}{$\begin{array}{l}\text { III, upper } \\
\text { third }\end{array}$} & 1947 & $\begin{array}{l}\text { Wheat } \\
\text { Barley }\end{array}$ & $\begin{array}{l}3 \\
0\end{array}$ & $\begin{array}{l}4 \\
4\end{array}$ & $\begin{array}{l}1 \\
0\end{array}$ & $\begin{array}{l}\text { Spring } \\
\text { Summer }\end{array}$ & $\begin{array}{l}\mathbf{0} \\
\mathbf{0}\end{array}$ & $\begin{array}{l}4 \\
4\end{array}$ & $\begin{array}{l}\mathbf{0} \\
\mathbf{0}\end{array}$ \\
\hline & 1948 & $\begin{array}{l}\text { Meadow grass } \\
\text { Oats }\end{array}$ & $\begin{array}{l}\mathbf{0} \\
\mathbf{3}\end{array}$ & $\begin{array}{l}4 \\
3\end{array}$ & $\begin{array}{l}0 \\
1\end{array}$ & $\begin{array}{l}\text { Spring } \\
\text { Summer }\end{array}$ & $\begin{array}{l}\mathbf{0} \\
\mathbf{0}\end{array}$ & $\begin{array}{l}4 \\
1\end{array}$ & $\begin{array}{l}\mathbf{0} \\
\mathbf{1}\end{array}$ \\
\hline \multirow[t]{2}{*}{$\begin{array}{l}\text { III, lower } \\
\text { third }\end{array}$} & 1947 & $\begin{array}{l}\text { Wheat } \\
\text { Meadow grass }\end{array}$ & $\begin{array}{l}\mathbf{3} \\
\mathbf{0}\end{array}$ & $\begin{array}{l}4 \\
4\end{array}$ & $\begin{array}{l}1 \\
0\end{array}$ & $\begin{array}{l}\text { Spring } \\
\text { Summer }\end{array}$ & $\begin{array}{l}\mathbf{1} \\
\mathbf{0}\end{array}$ & $\begin{array}{l}4 \\
4\end{array}$ & $\begin{array}{l}\mathbf{0} \\
\mathbf{0}\end{array}$ \\
\hline & 1948 & $\begin{array}{l}\text { Linseed } \\
\text { Wheat }\end{array}$ & $\begin{array}{l}\mathbf{0} \\
\mathbf{3}\end{array}$ & $\begin{array}{l}4 ? \\
4\end{array}$ & $\begin{array}{l}\mathbf{0} \\
\mathbf{1}\end{array}$ & $\begin{array}{l}\text { Spring } \\
\text { Summer }\end{array}$ & $\begin{array}{l}\mathbf{0} \\
\mathbf{0}\end{array}$ & $\begin{array}{l}4 \\
1\end{array}$ & $\begin{array}{l}\mathbf{0} \\
\mathbf{1}\end{array}$ \\
\hline \multirow[t]{2}{*}{ IV } & 1947 & $\begin{array}{l}\text { Beet } \\
\text { Oats }\end{array}$ & $\begin{array}{l}2 \\
3\end{array}$ & $\begin{array}{l}\mathbf{3} \\
\mathbf{3}\end{array}$ & $\begin{array}{l}1 \\
1\end{array}$ & $\begin{array}{l}\text { Spring } \\
\text { Summer }\end{array}$ & $\begin{array}{l}\mathbf{0} \\
\mathbf{0}\end{array}$ & $\begin{array}{l}4 \\
0\end{array}$ & $\begin{array}{l}\text { C } \\
\mathbf{I}\end{array}$ \\
\hline & 1948 & $\begin{array}{l}\text { Oats } \\
\text { Wheat }\end{array}$ & $\begin{array}{l}\mathbf{3} \\
\mathbf{3}\end{array}$ & $\begin{array}{l}3 \\
4\end{array}$ & $\begin{array}{l}1 \\
1\end{array}$ & $\begin{array}{l}\text { Spring } \\
\text { Summer }\end{array}$ & $\begin{array}{l}\mathbf{0} \\
\mathbf{0}\end{array}$ & $\begin{array}{l}4 \\
0\end{array}$ & $\begin{array}{l}\mathbf{0} \\
\mathbf{1}\end{array}$ \\
\hline
\end{tabular}

* The composition quoted for the microflora is that given by Lochhead et al. (1940) for the crop in question.

$\dagger$ Only one bank of Zone 2 is given, as the other was covered by old permanent grassland throughout the investigation.

(Prevalence of the bacterial types is indicated roughly on the scale: $0=a b s e n t, 1=$ present, $2=$ frequent, $3=$ numerous, $4=$ very numerous.

On this point, Dr A. G. Lochhead in a private communication observed that, regarding the extent to which changes are attributable to agricultural operations, from a quantitative standpoint the effect of soil is dependent upon 
such factors as size of stream, degree to which soil or soil washings are incorporated in the stream (rainfall, slope, etc.), and from a qualitative standpoint the chief effects would be due to change in cropping system, and heavy application of manure. In general, he concludes: ' $I$ should be inclined to think that in the case of a stream the microbiology of the soil and that of fresh water are more nearly reflexions of each other than in the case of a lake or more quiescent body of water.'

If this possible association be confirmed, it is of great importance, for such Gram-negative bacterial rods are the chosen food selected by protozoa, especially by the bacteria-eating ciliate protozoa (Singh, 1941, 1946) and as found during this investigation, when an association between Gram-negative rods and bacteria-eating ciliates proved to be statistically significant. The number of protozoa would increase from the additional food supply, and that this would have a destructive effect upon pathogenic Gram-negative bacteria present is suggested by the following observations.

\section{Pollution}

No true Esch. coli were at any time isolated from the Brook. At the beginning of the inquiry the whole stream was examined for the presence of this organism by putting up dilutions in the appropriate media and reading the results by Macready's tables, positive samples being subsequently plated out on bile-salt agar. True faecal coliforms, however, were not isolated. Two further examinations for Esch. coli were made in the spring and autumn of 1948 at the mouth of the tributary which enters at the junction of Zones II and III (Fig. 1). These 'presumptive coliform' tests showed that the numbers of the organism were $2-25 / 100 \mathrm{ml}$. at the junction, but pollution could not be traced more than a few yards below the effluent mouth. This was considered remarkable since the tributary is formed by the union of two small streams which run through a farmyard and drain some old cottages rather more than half a mile from the Brook. The tributary is only half the width of the Brook but as long as the stretch of the latter investigated, with a very slow current that at times is negligible, and it contains farmyard and household waste.

Following the initial tests at the mouth of the tributary therefore, in the spring and late summer of 1948 a presumptive Esch. coli test was made along its length within $24 \mathrm{hr}$. of heavy rain, to detect how far pollution might be washed into the stream. Six points were sampled (Fig. 1), viz. on each tributary stream-points $A$ and $B$; at $C$, approximately 100 yards below their union; at two equidistant points below this $-D$ and $E$; and finally, at $F$, in the Brook approximately 50 yards below the mouth of the tributary. At the spring examinations the numbers of Esch. coli were (numbers $/ 100 \mathrm{ml}$.) at points $A$ and $B 180+$; at $C, 90$; at $D-F$, none. At the autumn test only points $C-F$ were sampled, the numbers of presumptive coliforms $/ 100 \mathrm{ml}$. being: $180+$ at points $C$ and $D ; 90+$ at $E ; 2-25$ at $F$ (Fig. 6). The writer was informed that during May and August 1938 a presumptive coliform test was carried out by the Public Health authorities in order to detect how far 
infection was carried into the Brook, but no degree of impurity was detected at either examination. It would appear therefore that in its course of about half a mile the tributary largely rids itself of coliform infection, and the agreement between the examinations carried out by the Public Health authorities in 1938 and the examinations in 1948 indicates that it has continued to do so.

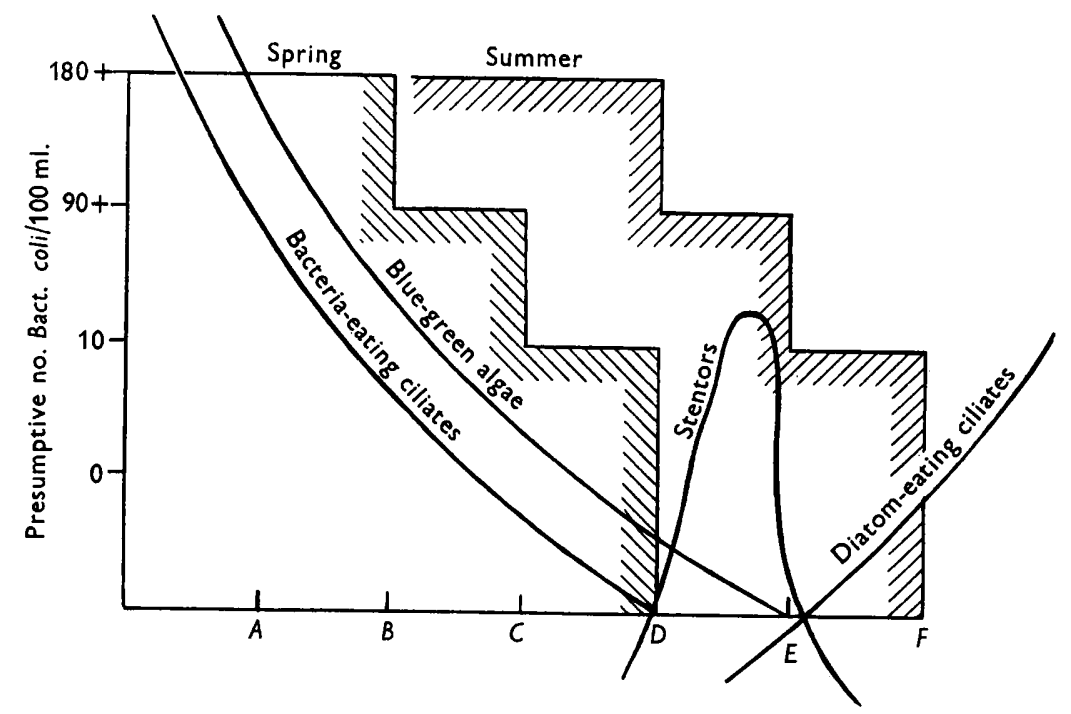

Fig. 6. The incidence of coliform infection in the tributary, tested at the six sampling points within 24 hr. of heavy rain, and the dominant ciliate Protozoa, in the spring and late summer of 1948 .

As this fact was of considerable interest, a number of examinations were made to detect how it might occur. Turbulence followed by sedimentation was considered to be partly responsible. The Brook water of Zone II pours into Zone III at a right angle, cutting across the water entering from the tributary to impinge against the opposite bank of Zone III; the current from Zone II was so swift that the black mud of the tributary floor was commonly cut off as if with a knife. The turbulent flow from Zone II, it was thought, would dilute the bacterial numbers in the tributary water whilst sedimentation occurred at the opposing bank, additional sand and mud bars often being thrown up across the entrance to Zone III. The effect was shown by sampling the bacterial numbers in Zone II, at points across the junction of Zone II, the tributary and Zone III, and at 50-100 yards downstream in Zone III (Fig. 7). But these physical factors were regarded as subordinate to the activity of protozoa.

The phagocytic activity of ciliate protozoa in particular was regarded as the major factor in clearing pollution. It has been mentioned that in the Brook an association between Gram-negative rods and bacteria-eating ciliate protozoa proved to be statistically significant. It was further noted here that whereas bacteria-eating ciliates such as Colpoda and Colpidium were associated with 
strains of Pseudomonas and multiplied when they were abundant, Paramoecidae were associated with typical strains of Esch. coli. Taylor \& Strickland (1938) used a strain of Pseudomonas as food for their cultures of Colpoda duodenarii. In the tributary the curve of coliform infection was closely followed by the curve of bacteria-eating ciliate protozoa, notably Paramoecium caudatum,

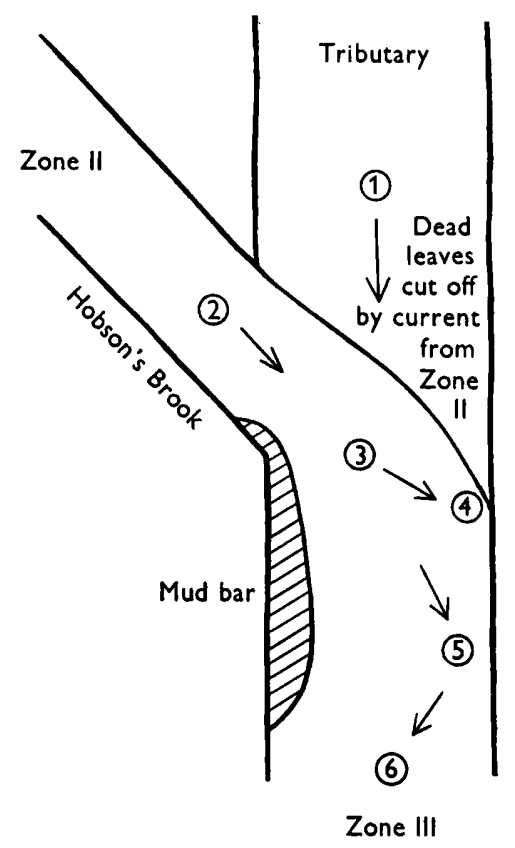

Fig. 7. The viable counts at $22^{\circ}$ at the junctions of Zone II and III and the tributary in May 1948. Diagram of the junction and showing observation points referred to in the table below. Distance from point 2 to point 6 approximately $5 \mathrm{yd}$. Arrows indicate direction of flow.

$\begin{array}{ccccc}\text { Point } & \begin{array}{c}\text { Temp. } \\ \left({ }^{\circ} \text { C. }\right)\end{array} & \text { pH } & \begin{array}{c}\text { Viable } \\ \text { count } \\ (\mathbf{2 2})^{2}\end{array} \\ 1 & 15 & 7 \cdot 3 & 4 \cdot 1 & 1.1 \\ 2 & 12 & 7 \cdot 3 & 6 \cdot 9 & 7 \\ 3 & 13 & 7 \cdot 3 & 4 \cdot 8 & 9 \\ 4 & 15 & 7 \cdot 3 & - & 11 \\ 5 & 15 & 7 \cdot 3 & - & 19 \\ 6 & 15 & 7 \cdot 3 & - & 14\end{array}$

At point 1 diatoms and diatom-eating ciliate protozoa were found. No infusoria at points 2-5. At point 6 bacteria-eating ciliate protozoa appeared.

$P$. bursaria and other forms of Paramoecidae. These organisms were present almost to the exclusion of all others wherever pollution was highest (Fig. 6). Indeed, the typical microscopical picture of the tributary water, its heavy organic-matter content, faecal pollution and teeming population of Paramoecidae was very reminiscent of that found in 1844 in the Thames near 
sewer mouths by Hassall (1850, 1855), whose observations prompted this inquiry. Further, whenever surface water from prolonged heavy rain or heavy storms flooded down the tributary and turbidity was seen to enter the Brook, populations of bacteria-eating ciliate protozoa, especially of Paramoecidae, appeared in the upper third of Zone III and subsequently disappeared.

\section{Effects of the biota of the Brook}

In the Brook there was at all times an abundant phytoplankton of diatoms. There were also 'blooms' of blue-green Algae (Oscillatoria) which floated down the stream. In addition there were the flowering plants (Phanerophyta) characteristic of alkaline streams, e.g. Nasturtium officinale, Veronica anagallis, Apium nodiflorum and Ranunculus trichophilus. These were seasonal in appearance, being most abundant in autumn in Zone III. Bacterial numbers were always greatest in relation to plants, and highest of all in relation to blue-green algae, 'blooms' of which floated down from Zone II to Zone IV in October 1946, March 1947, and January 1948 (Table 9). These high numbers did not appear to be reflected in the routine samplings, since it was usually found that they did not persist more than a foot or two downstream below the plant, or on occasion immediately in front of it upstream. The same was generally true of all fixed objects in the current core (Table 9). Nevertheless, care was taken wherever possible to sample from clear water not less than 4-6 ft. from any obstacle. There was some indication that chromogenic bacteria (other than strains of Chromobacterium violaceum and Flavobacterium spp.) were more common near plants and other obstacles than elsewhere (Table 9).

There was no free-floating zooplankton in the stream. Ciliate protozoa were most abundant on objects in the centre of the stream, for example on the leaves of plants, but their numbers were depressed each year by a late summer peak of dipterous larvae, e.g. Simulidae (blackfly) and Chironomidae (midges), which occupied the centre of the stream. Barker (1946) found an identical relation in sewage filter-beds, where seasonal peaks of fly output were accompanied by a decrease of ciliate protozoa. This decrease in numbers of ciliates would be expected to raise the numbers of those bacteria on which they feed, and this may have contributed to obscure any diminution in numbers caused by higher summer temperatures.

The close association found during the investigation between the bacteria of the stream and the bacteria of the arable land through which it runs, the relation of bacterial numbers and types to plants seasonal in appearance, and the annual decrease caused by fly larvae of ciliate protozoa which feed upon bacteria, emphasize the importance of studying the bacteria of such waters in relation to their ecology as a whole.

The writer is glad to express his gratitude to the Department of Scientific and Industrial Research for a grant which enabled the study to be carried out, and to Prof. F. T. Brooks, F.R.S., for permission to work at the School of Botany. 
Table 9. Viable counts at $\mathbf{2 2}^{\circ}$ and chromogenic bacteria in the vicinity of fixed objects in the stream

\begin{tabular}{|c|c|c|c|c|c|c|c|c|}
\hline \multirow[b]{2}{*}{ Date } & \multirow[b]{2}{*}{ Zone } & \multirow[b]{2}{*}{ Object } & \multicolumn{4}{|c|}{ Number of bacteria $\left(10^{3} / \mathrm{ml}.\right)$} & \multicolumn{2}{|c|}{$\begin{array}{c}\begin{array}{c}\text { Chromogenic } \\
\text { bacteria }\end{array} \\
\text {. }\end{array}$} \\
\hline & & & $\begin{array}{c}\text { At } \\
\text { object }\end{array}$ & $\begin{array}{c}3 \mathrm{ft} . \\
\text { up- } \\
\text { stream }\end{array}$ & $\begin{array}{l}3 \mathrm{ft} . \\
\text { down- } \\
\text { stream }\end{array}$ & $\begin{array}{l}\text { Current } \\
\text { core }\end{array}$ & $\begin{array}{c}\text { At } \\
\text { object }\end{array}$ & 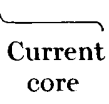 \\
\hline 31. i. 47 & III & $\begin{array}{l}\text { Edge of brick } \\
\text { arch }\end{array}$ & $\mathbf{5}$ & 8 & 4 & 4 & • & . \\
\hline 28. i. 47 & III & Rỏtting sack & 36 & $4 \cdot 5$ & $9 \cdot 5$ & . & - & - \\
\hline 5. ii. 47 & III & Rotting sack & 72 & 141 & 10 & . & 14 & 5 \\
\hline 10. ii. 47 & II & $\begin{array}{l}\text { Mass of rotting } \\
\text { vegetation }\end{array}$ & 44 & 19 & 136 & . & 7 & 5 \\
\hline 17. $x .46$ & IV & Blue-green alga & 500 & 262 & - & - & . & - \\
\hline 29. iv. 47 & II & $\begin{array}{l}\text { Grass-green algae } \\
\text { on sandbar }\end{array}$ & 688 & 52 & 34 & - & 13 & $\mathbf{0}$ \\
\hline 29. vii. 47 & III & Grass-green alga & 142 & 11 & - & 15 & 20 & - \\
\hline $9 . x \cdot 47$ & III & Alga (Spirogyra) & 736 & 40 & . & 16 & . & $\cdot$ \\
\hline $9 . \times .47$ & IV & Alga (Cladophora) & 520 & 1200 & - & - & . & . \\
\hline 31. x. 47 & III & Diatoms & 468 & 40 & - & - & - & - \\
\hline $31 . \times \cdot 47$ & IV & Diatoms & 168 & 120 & . & - & - & . \\
\hline 9. ii. 48 & II & $\begin{array}{l}\text { Old grass green } \\
\text { algae }\end{array}$ & 40 & $12 \cdot 5$ & 11 & 3 & 6 & . \\
\hline 11. iii. 47 & IV & Flowering plant & 68 & 4 & - & - & 16 & - \\
\hline 10. v. 47 & III & Flowering plant & 56 & 11 & 54 & 9 & 12 & - \\
\hline 5. vi. 47 & II & Flowering plant & 44 & . & . & - & 1 & . \\
\hline 5. vi. 47 & III & Flowering plant & 16 & . & . & . & . & . \\
\hline 5. vi. 47 & IV & Flowering plant & 52 & . & . & - & 12 & - \\
\hline 10. vi. 47 & II & Flowering plant & 88 & . & - & $\begin{array}{l}6 \text { at the } \\
\text { bi-monthl } \\
\text { test } 13 / 6\end{array}$ & ly & $\cdot$ \\
\hline 10. vi. 47 & III & Flowering plant & 78 & - & - & $\begin{array}{l}32 \text { at test } \\
\text { above }\end{array}$ & 4 & 3 \\
\hline 10. vi. 47 & IV & Flowering plant & 148 & - & • & $\begin{array}{l}36 \text { at test } \\
\text { above }\end{array}$ & 6 & $\cdot$ \\
\hline 5. vii. 48 & III & Flowering plant & 87 & . & . & 11 & 4 & . \\
\hline
\end{tabular}

\section{REFERENCES}

Barker, N. A. (1946). Ecology and function of Protozoa in sewage purification. Ann. appl. Biol. 33, 3.

Carpenter, K. (1928). Life in Inland Waters. London: Sidgwick \& Jackson.

Gray, E. \& Smith, J. D. (1950). A new aquatic nitrogen-fixing bacterium from three Cambridgeshire chalk streams. J. gen. Microbiol. 4, 3.

Hassall, A. H. (1850). A Microscopic Examination of the Water supplied to the Inhabitants of London and the Suburban Districts. London: Highley.

Hassall, A. H. (1855). Food and its Adulterations. London: Longmans.

Katznelson, H., Lochread, A. G. \& Timonin, M. I. (1948). Soil Microorganisms and the rhizosphere. Bot. Rev. 14, 9, 543.

Lochread, A. G., Timonin, M. I. \& West, P. M. (1940). Microflora of the rhizosphere in relation to the resistance of plants to soil-borne pathogens. Sci. Agric. 20, 4.14 .

Ministry of Health (1939). Bacteriological examination of water supplies. Rep. Minist. Hlth, Lond., no. 71.

Schmelch, L. (1888). Steigerung des Bacteriengehalts im Wasser während des Schneeschmelzens. Z Zbl. Bakt. 4, 195. 
Journal of General Microbiology, Vol. 5, No. 5

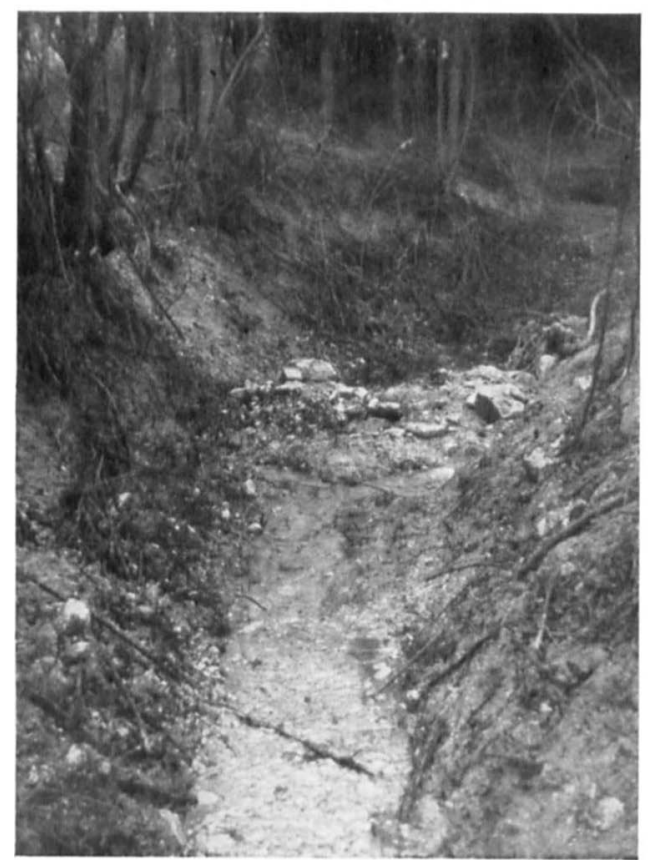

Fig. 1

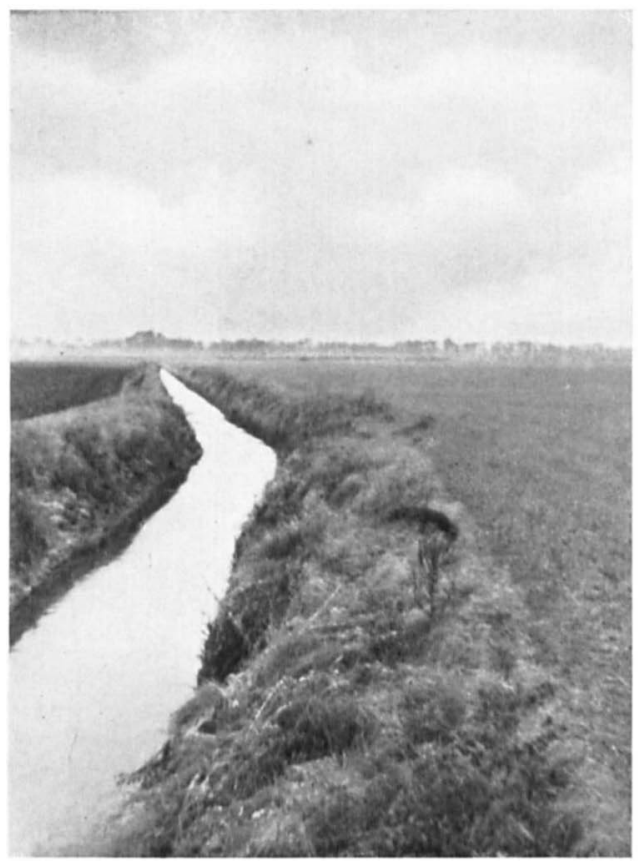

Fig. 3

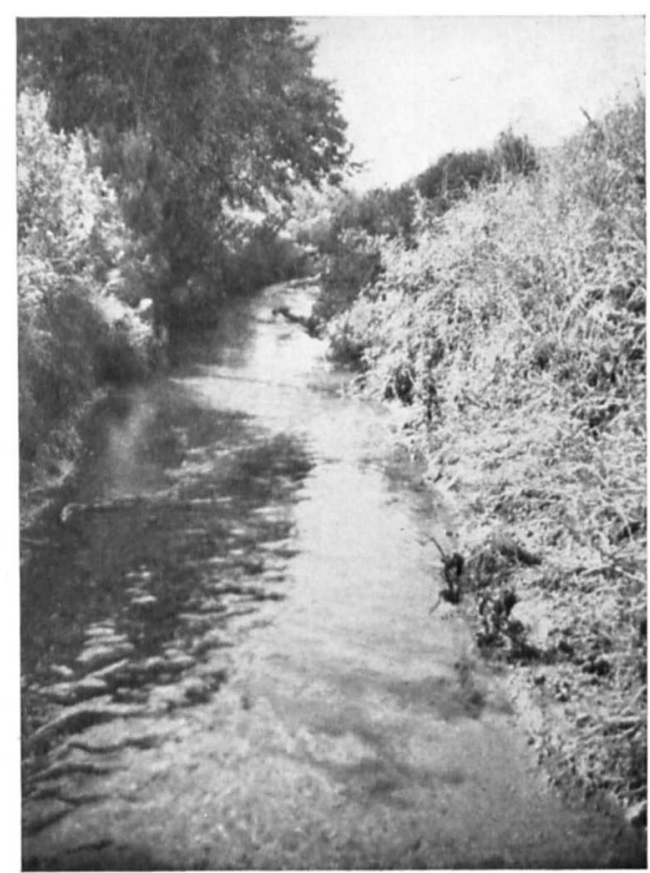

Fig. 2

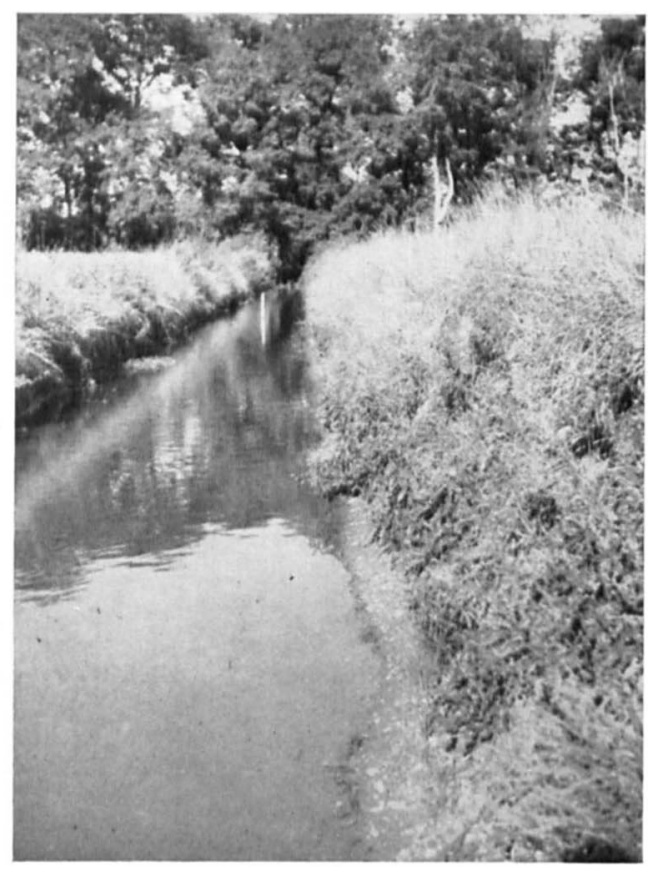

Fig. 4

F. Gray-Bacterial ecology of a chalk stream. Plate 1 
Journal of General Microbiology, Vol. 5, No. 5

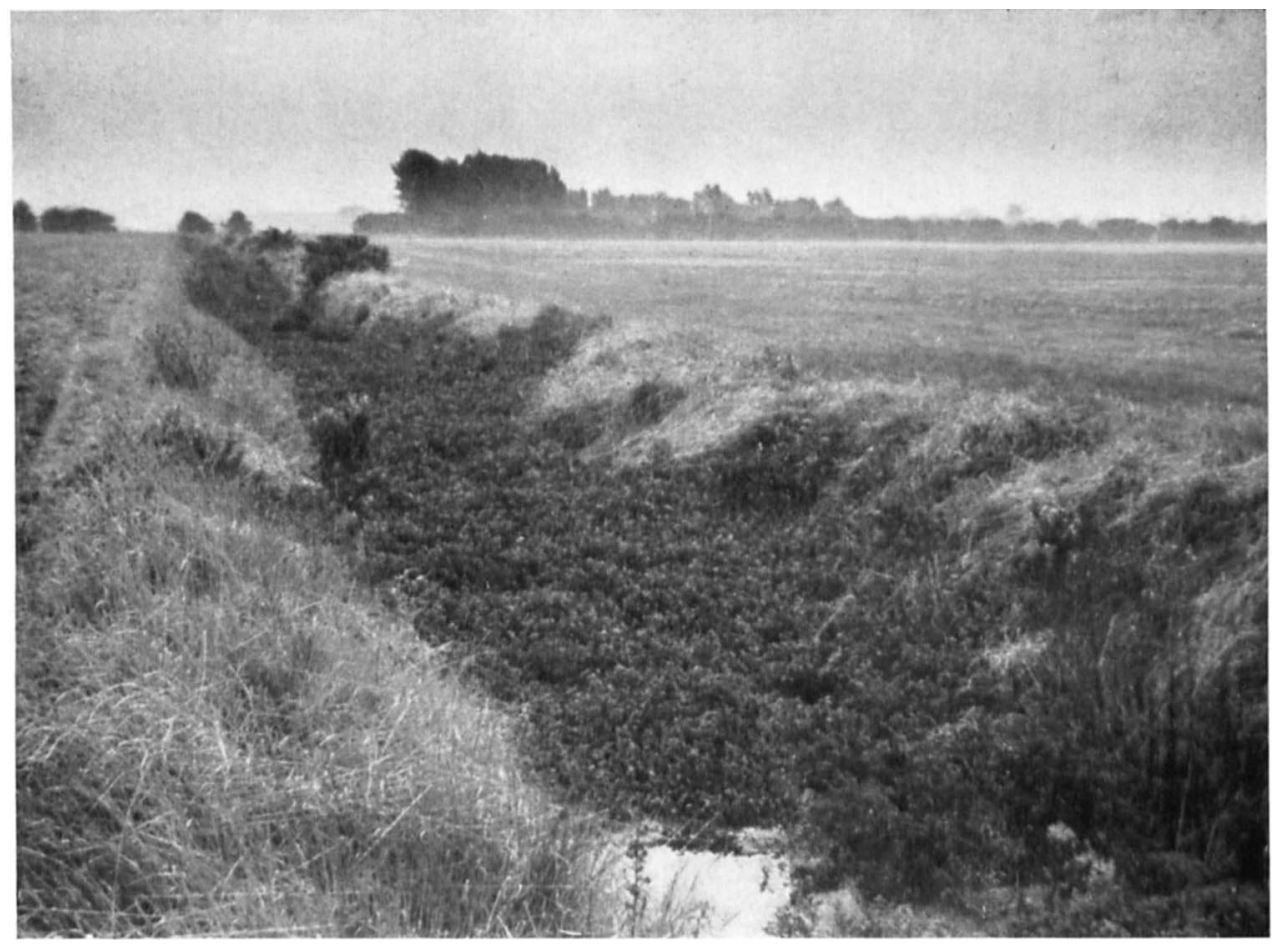

Fig. 5

E. Gray-Bacterial ecology of a chalk stream. Piate 2 
Singh, B. N. (1941). Influence of different bacterial food supplies on the rate of reproduction in Colpoda steinii and the factors influencing encystation. Ann. appl. Biol. 28, 65.

Singh, B. N. (1946). A method of estimating numbers of soil Protozoa, especially amoebae, based on differential feeding of bacteria. Ann. appl. Biol. 33, 112.

Sonneborn, T. M. (1932). Experimental production of chains and its genetic consequences in the ciliate protozoon Colpidium campylum (Stokes). Biol. Bull. Woods Hole, 63, 2.

TAYlOR, C. B. (1942). Bacteriology of fresh water. J. Hyg., Camb., 42, 284.

Taylor, C. V. \& Strickland, A. G. (1938). Reaction of Colpoda to some environmental factors. Arch. Protistenk. 90, 396.

Thomas, S. B. \& Sekhar, Chandra C. V. (1946). Psychrophilic bacteria in raw and commercially pasteurised milk. Proc. Soc. appl. Bact. 1, 47.

Topley and Wilson's Principles of Bacteriology and Immunity (1946). 3rd ed. revised by Wilson, G. S. \& Miles, A. A. London: Arnold and Co.

Waksman, S. A. (1927). Principles of Soil Microbiology. London: Baillière, Tindall and Cox.

WARD, M. H. (1898). A violet bacterium from the Thames. Ann. Bot., Lond., 12, 59.

\section{EXPLANATION OF PLATES}

\section{Plate 1}

Fig. 1. The Nine Wells springs. The particular spring sampled during the investigation is shown. The water breaks through fissures in a chalk face (hidden by the right hand bank) with sufficient force to produce a spurt of foam clearly visible near the right centre of the photograph.

Fig. 2. The gravel reach of Hobson's Brook. (Zone II).

Fig. 3. The centre of the rural reach (Zone III) in winter 1947 .

Fig. 4. Zone IV in summer 1948, looking towards the main road (in the trees behind) which limited the rural reach of the Brook. At the end of the reach is the graduated post for measuring the water volume.

\section{Prate 2}

Fig. 5. The abnormal growth of Nasturtium officinale in the centre of the rural reach (Zone III) following heavy manuring of the arable land on the banks.

(Received 21 February 1951) 